University of Nebraska - Lincoln

DigitalCommons@University of Nebraska - Lincoln

Evaluation of Three Breeding Cycles for Seedling Weight of Switchgrass, Big Bluestem, and Indiangrass

\author{
Boingotlo Sebolai \\ Botswana College of Agriculture \\ Kenneth P. Vogel \\ University of Nebraska-Lincoln, kvogel1@unl.edu
}

Follow this and additional works at: https://digitalcommons.unl.edu/usdaarsfacpub

Sebolai, Boingotlo and Vogel, Kenneth P., "Evaluation of Three Breeding Cycles for Seedling Weight of Switchgrass, Big Bluestem, and Indiangrass" (2014). Publications from USDA-ARS / UNL Faculty. 1976. https://digitalcommons.unl.edu/usdaarsfacpub/1976

This Article is brought to you for free and open access by the U.S. Department of Agriculture: Agricultural Research Service, Lincoln, Nebraska at DigitalCommons@University of Nebraska - Lincoln. It has been accepted for inclusion in Publications from USDA-ARS / UNL Faculty by an authorized administrator of DigitalCommons@University of Nebraska - Lincoln. 


\title{
Evaluation of Three Breeding Cycles for Seedling Weight of Switchgrass, Big Bluestem, and Indiangrass
}

\author{
Boingotlo Sebolai and Kenneth P. Vogel`
}

\begin{abstract}
A modified form of restricted, recurrent phenotypic selection was used to select for seedling shoot weight in switchgrass (Panicum virgatum L.), big bluestem (Andropogon gerardii Vitman), and indiangrass [Sorghastrum nutans (L.) Nash] populations for three generations. Seedlings were grown in micropots in trays in a greenhouse and were individually clipped and weighed $4 \mathrm{wk}$ after emergence. The seedlings were allowed to regrow, and the heaviest seedlings were transplanted to field nurseries for polycrossing to produce Syn 1 seed. Three breeding cycles were conducted for each grass. After the third breeding cycle, Syn 2 generation seed was produced for each cycle, including cycle 0 for $2 \mathrm{yr}$, and was used in subsequent greenhouse and field evaluations to determine if the breeding procedure improved seedling vigor as measured by seedling shoot weight. In two greenhouse evaluation trials, the increase in seedling weight per cycle was 7.8, 5.6, and $10.2 \%$ for big bluestem, switchgrass, and indiangrass, respectively. In two field trials, seedling weight also increased with successive cycles of selection except for indiangrass in one trial. Establishment success as measured by stand counts did not differ among the cycles of selection for the three grasses in the field trials. Based on these results and the results of subsequent breeding and field evaluation work on seedling tiller number, it is apparent that seedling traits of these grasses can be modified by breeding. To improve establishment of these grasses, research on developing agronomic seed production practices that result in improved seed quality would also be beneficial.
\end{abstract}

B. Sebolai, Botswana College of Agriculture, Private Bag 0027, Gaborone, Bostwana; K.P. Vogel, USDA-ARS (retired), 137 Keim Hall, PO Box 830937, Univ. of Nebraska-Lincoln, Lincoln, Lincoln, NE 68583-0937. Received 27 Sept. 2013. *Corresponding author (VogelKP61@neb.rr.com).

Abbreviations: ARDC, Agricultural Research and Demonstration Center; C0, base population; C1, Cycle 1; C2, Cycle 2; C3, Cycle 3;

Cwitchgrass has been under development as a perennial bio$\checkmark$ mass energy crop since the early 1990s. Two other perennial warm-season grasses native to the North American tall grass prairie, big bluestem and indiangrass, are also under development for use in polycultures with switchgrass as bioenergy crops. These grasses have been used in warm-season pastures in the Great Plains for over $50 \mathrm{yr}$. In the past, these grasses have been difficult to establish because their seedlings are not as vigorous as annual weeds, including warm-season weedy grasses. The recent development of herbicides that can be used to control annual grassy weeds in these grasses during establishment has significantly improved establishment success (Masters, 1995, Masters et al., 1996; Mitchell et al., 2010, 2012; Washburn and Barnes, 2000). On-farm trials and associated economic and net energy analyses with switchgrass have clearly demonstrated the importance of obtaining good stands in the establishment year in biomass production fields (Perrin et al., 2008; Schmer et al., 2006, 2008). If good stands can be achieved, biomass can be harvested after a killing frost in the establishment year, and the fields can be at full production the first post-establishment year (Mitchell et al., 2012). Because of the economic value of obtaining excellent, harvestable stands of these grasses in the establishment year, there is a renewed interest in improving seedling vigor and stand establishment capability in these grasses

Published in Crop Sci. 54:1354-1360 (2014).

doi: 10.2135/cropsci2013.09.0643

(C) Crop Science Society of America | 5585 Guilford Rd., Madison, WI 53711 USA

All rights reserved. No part of this periodical may be reproduced or transmitted in any form or by any means, electronic or mechanical, including photocopying, recording, or any information storage and retrieval system, without permission in writing from the publisher. Permission for printing and for reprinting the material contained herein has been obtained by the publisher. 
Grass breeders have attempted to improve the establishment of perennial grasses by breeding for seedling vigor and associated traits. McKell (1972) indicated that most biologists used the term 'seedling vigor' to describe a vigorous growth habit that involves a more rapid size increase than that of competing plants of the same age. Kneebone (1972) defined seedling vigor as the capacity for rapid seedling growth which, by implication, increases the probability of stand establishment. The principal selection criteria that have been used in breeding programs to improve seedling vigor and establishment success in perennial grasses have been seed size or weight, rate of emergence, emergence from deep seeding, and seedling vigor scores with some success (Kneebone, 1972; Voigt and Brown, 1969; Wright, 1977, 1978, 1980). The effects of these breeding changes on establishment success have varied. The switchgrass cultivar 'Sunburst,' which was developed by selecting for seed weight and other traits, had improved establishment when compared with other adapted switchgrass cultivars (Boe and Ross, 1998). Glewen and Vogel (1984) partitioned the genetic variability for seedling vigor in sand bluestem [Andropogon gerardii Vitman var paucipilus (Nash) Fern] into its seed size and seedling vigor per se components. Half of the genetic variability for seedling weight in sand bluestem was due to seed weight and the other half was due to seedling vigor as measured by seedling shoot weight. Genetic correlation between the traits was 0.70. Glewen and Vogel (1984) proposed that selection for seedling weight per se in grasses would improve seedling vigor as measured by seedling weight by improving both seed size and seedling weight.

In this study, we report on the effectiveness of a stratified mass selection breeding system to improve seedling vigor and establishment of switchgrass, big bluestem, and indiangrass by selection for seedling weight in three breeding generations. The objectives were to determine if the three cycles of stratified mass selection for seedling shoot weight improved the seedling vigor of the grasses as measured by seedling weight, determine if relative performance of the populations was consistent over years of seed production, and to determine if any changes in seedling shoot weight improved stand establishment in the field.

\section{MATERIALS AND METHODS Breeding Procedures}

Breeding work to improve seedling vigor of switchgrass, big bluestem, and indiangrass was initiated in 1978 by K.P. Vogel. The base populations used were foundation seed lots of 'Pathfinder' switchgrass, 'Pawnee' big bluestem, and a commercial seed lot of 'Nebraska 54' indiangrass. In each breeding cycle, selection was conducted in the greenhouse during the winter months, and selected seedlings were transplanted in a completely randomized design into isolated field polycross nurseries to produce seed used in the next breeding cycle. Polycross nurseries were separated by a distance of at least $400 \mathrm{~m}$. Selection was conducted by growing seedlings individually in Cone-tainer cells (Stuewe \& Sons Inc, Tangent, Oregon). Each cell was filled with a mixture of loam soil, peat, and vermiculite at a volume ratio of 2:1:1. Two to three seeds were planted in each cell, and the trays were treated with Captan [cis-N-(trichloromethyl) thio)-4-cylohexene-1-2-dicarboximide] at a rate of $2 \mathrm{~g} \mathrm{~m}^{-2}$ of soil surface to prevent damping off. After emergence, each cell was thinned to one seedling per cell. At $4 \mathrm{wk}$ after emergence, which was about 5 to 6 wk after planting, seedlings were clipped to a centimeter above the soil surface and the fresh weight of each seedling was determined. The seedlings were fertilized with a commercial greenhouse fertilizer solution and then allowed to regrow. Seedling fresh weight was the selection criterion. Super-cell cone-tainers were used in all cycles for big bluestem and Cycles 2 and 3 for switchgrass and indiangrass. The super-cell cone-tainer cells are $21.6-\mathrm{cm}$ deep and $3.8 \mathrm{~cm}$ in diameter at the top and a tray holds 98 cells (14 rows with 7 plant cells per row). Smaller fir cone-tainers cells, which are $12.1-\mathrm{cm}$ deep and $2.5 \mathrm{~cm}$ in diameter with 200 cells per tray (20 rows of ten cells), were used for breeding Cycle 1 (C1) for switchgrass and indiangrass.

In C1 for switchgrass and indiangrass, each tray of 200 cells was stratified into 10 selection units of 2 adjacent rows of 10 plants. Within each selection unit of 20 seedlings, the single heaviest seedling was selected. In C1 for big bluestem, the selection unit was one-half of a tray with 49 seedlings. The two heaviest seedlings per 49 seedling selection unit were selected. In the second cycle of selection, the greenhouse selection procedure used for big bluestem in C1 was used for all three species. In the third cycle of selection for all species, the heaviest seedling from the border and the interior of $1 / 2$ of a tray was selected plus the next heaviest seedling from the entire interior of a tray was selected. Each change in the selection procedure with generation of breeding was done to reduce environmental variation in the selection environment. The selection population sizes for each generation and the number of selected seedlings are listed in Table 1. Each generation, a selection population of 2000 or more seedlings was the goal, except for C1 with big bluestem where the desired selection population size was 3000 seedlings. The selection intensity was about $5 \%$ but was adjusted with cycle and species to ensure that the selected seedling population size was approximately 100 plants to reduce potential inbreeding effects. Standardized selection differentials were calculated by subtracting the mean seedling weight of a selection population from the mean of the selected seedlings and then dividing by the standard deviation of the selection population.

The selected seedlings were transplanted in isolated polycross nurseries at the University of Nebraska's Agricultural Research and Demonstration Center (ARDC) which is $50 \mathrm{~km}$ west of Omaha, NE. The seedlings were transplanted on $1.1 \mathrm{~m}$ centers in the polycross nurseries which were kept weed free by annual spring applications of atrazine [6-chloro-N-ethyl-N'(1-methylethyl)-1,3,5-triazine-2,4-diamine] at $2.24 \mathrm{~kg} \mathrm{ha}^{-1}$, rototilling, and hoeing. They were fertilized in the spring of each year with $112 \mathrm{~kg} \mathrm{ha}^{-1}$ of $\mathrm{NH}_{4} \mathrm{NO}_{3}$. In the autumn of the polycross establishment year, Cycle 2 (C2), or the following year (C1 and Cycle 3 [C3]) for all grasses, Syn 1 seed was harvested from each individual plant in a polycross nursery, and an equal amount of seed from each plant was bulked by species to produce the Syn 1 seed lot that was used for the next cycle of selection. 
Table 1. Population size, mean seedling shoot weight, standard deviation (s), and the standardized selection differential (i) for the evaluated and selected populations for each cycle of selection in the greenhouse for seedling weight in switchgrass, big bluestem, and indiangrass. ${ }^{\dagger}$

\begin{tabular}{|c|c|c|c|c|c|c|c|}
\hline \multirow[b]{2}{*}{ Cycle } & \multicolumn{3}{|c|}{ Evaluated population } & \multicolumn{4}{|c|}{ Selected plants } \\
\hline & $\mathrm{n}$ & mean & s & $\mathrm{n}$ & mean & s & $i$ \\
\hline & \multicolumn{4}{|c|}{- g seedling $^{-1}-$} & \multicolumn{3}{|c|}{ - g seedling $^{-1}$} \\
\hline \multicolumn{8}{|c|}{ Switchgrass } \\
\hline Cycle 1 & 1730 & 0.350 & 0.113 & 100 & 0.508 & 0.081 & 1.40 \\
\hline Cycle 2 & 1311 & 0.379 & 0.102 & 105 & 0.530 & 0.053 & 1.48 \\
\hline Cycle 3 & 1953 & 0.289 & 0.106 & 105 & 0.414 & 0.092 & 1.18 \\
\hline \multicolumn{8}{|c|}{ Indiangrass } \\
\hline Cycle 1 & 1543 & 0.187 & 0.065 & 97 & 0.302 & 0.044 & 1.77 \\
\hline Cycle 2 & 1742 & 0.387 & 0.100 & 105 & 0.544 & 0.047 & 1.57 \\
\hline Cycle 3 & 1801 & 0.203 & 0.094 & 105 & 0.313 & 0.093 & 1.17 \\
\hline \multicolumn{8}{|c|}{ Big bluestem } \\
\hline Cycle 1 & 2831 & 0.376 & 0.152 & 124 & 0.675 & 0.152 & 1.79 \\
\hline Cycle 2 & 1999 & 0.282 & 0.084 & 105 & 0.417 & 0.068 & 1.61 \\
\hline Cycle 3 & 1953 & 0.272 & 0.126 & 105 & 0.395 & 0.160 & 0.98 \\
\hline
\end{tabular}

${ }^{\dagger} \mathrm{n}$, number of individuals in the population.

\section{Evaluation Trials}

The Syn 1 seed produced by the original polycross nurseries of each cycle was advanced to the Syn 2 generation for use in the greenhouse and field valuation trials. This was necessary because the Syn 1 seed from the different breeding cycles was produced in different years and, although the seed was stored in a chilled seed storage room, use of the Syn 1 seed in previous evaluation trials (Weiler, 1984) produced inconsistent results. The Syn 2 polycross nurseries were established by growing 200 seedlings in the greenhouse from the Syn 1 seed and transplanting them into isolated field polycross nurseries. Since all three grasses are cross-pollinated, it was necessary to have four different polycross nurseries for each grass (base population [C0], C1, C2, and C3). All isolations for a species were located on the same section of land at the ARDC and were separated by approximately $400 \mathrm{~m}$. All isolations were located on the same soil type. Seed that was harvested in bulk from each isolation in successive years was used in the evaluation trials.

Two successive greenhouse trials were conducted in late winter and early spring of 1988. Seedlings from the C0, C1, C2, and C3 populations for each species were grown in super-cell cone-tainers using the same procedures as in the selection trials. One-half of the super-cell tray with 49 seedlings was a plot or experimental unit. Before planting, germination tests were conducted on all if the seed lots. The 1987 indiangrass C0, C1, C2, and $\mathrm{C} 3$ seed lots, which exhibited some dormancy, were cold chilled on wet blotter paper for $7 \mathrm{~d}$ before planting to break dormancy. Three or four seeds were planted per cone-tainer cell and were thinned to one per cone-tainer cell after emergence. The greenhouse experiments were carefully watered by hand using a hand wand. The seedlings were harvested by clipping them at the soil surface $6 \mathrm{wk}$ after planting and then weighing to determine fresh seedling weights. The seedlings were clipped at the soil surface because they were not needed for later transplanting. The harvested seedlings were then oven dried and reweighed. The average seedling fresh and dry weight per plot (plot seedling weight/number of harvested seedlings) was used in the analysis.
The experimental design was a split-split-plot with grasses as the main plot, year of seed production (year) as the split plot, and breeding cycles as split-split plots. Each trial was a randomized complete block with six replicates. Although grasses were the main plots in the greenhouse experimental design, the data for each grass was analyzed separately. Homogeneity of variances between trials was tested using a simple F-test. Since variances were homogenous, an over trials analyses was conducted.

Field evaluation trials were conducted in plantings at Lincoln Agronomy Farm and ARDC near Mead, NE in 1988. Plots were single rows $6.1-\mathrm{m}$ long and were spaced $1.1 \mathrm{~m}$ apart. Plots were seeded with a single row cone seeder with a seeding depth of $1 \mathrm{~cm}$. The seeding rate was 67 pure live seeds (PLS) per meter or row which is equivalent to the recommended seeding rate for these grasses in this region. The statistical design for the field trials was the same as for the greenhouse trials. At each location, the seeded trial was a split-split-plot with grasses as the main plot, year of seed production (year) as the split plot, and breeding cycles as split-split plots. The Mead trial was planted on May 27 and the Lincoln trial was planted on June 8, 1988. Seedlings were harvested on July 21 and 22 at Mead and August 28 to 30 at Lincoln. The differences in harvest dates were due to differences in rainfall patterns. The Lincoln nursery did not receive any rain until 4 wk after planting. At harvest, stand counts were obtained by laying a two meter stick next to the row and counting the number of $1 \mathrm{~cm}$ sections of the two meters that was occupied by a seeded grass seedling. Counted seedlings were hand clipped at the soil surface, their numbers recorded, and were weighed on a plot basis. The harvested seedlings were oven dried. Fresh and dry weights were divided by seedling numbers to obtain average seedling weight per plot which was used in the statistical analyses.

In the statistical analyses, breeding cycles were assumed to be fixed effects while years of seed production and replications were assumed to be random effects. Trials were assumed to be fixed effects since they were the only ones conducted. In the analyses of variance which was conducted using Proc GLM of SAS (SAS Institute, 1989), the cycle $\times$ year mean square was used as the error term for testing the significance of the cycle effects. Response to selection was determined by regressing mean values to the breeding cycle means as described by Falconer (1981). Seedling stand counts were transformed to the square root $\mathrm{X}$ to normalize and stabilize error variances.

\section{RESULTS AND DISCUSSION Selection Cycles}

In each of the selection cycles for all three species, there was considerable variation among seedlings for seedling weight, resulting in a relatively large selection differential in each breeding cycle (Table 1). It should be noted that the average seedling weight for both the total and selected subpopulation varied considerably among cycles for all three grasses. This is likely due to field environmental conditions during the different seed production years for the successive breeding cycles.

\section{Greenhouse Evaluation Trials}

In the greenhouse breeding progress evaluation trials, years of seed production and the breeding cycle $\times$ year of seed 
Table 2. Analysis of variance for fresh and dry seedling weight per seedling for combined greenhouse experiments in which breeding progress from three cycles of selection for increased seeding weight was evaluated for parent and C1, C2, and C3 switchgrass, indiangrass, and big bluestem populations.

\begin{tabular}{|c|c|c|c|c|c|c|c|}
\hline \multirow[b]{3}{*}{ Source of variation } & \multirow[b]{3}{*}{ df } & \multicolumn{6}{|c|}{ Mean squares } \\
\hline & & \multicolumn{2}{|c|}{ Switchgrass } & \multicolumn{2}{|c|}{ Indiangrass } & \multicolumn{2}{|c|}{ Big bluestem } \\
\hline & & Fresh weight & Dry weight & Fresh weight & Dry weight & Fresh weight & Dry weight \\
\hline & & & & - $\mathrm{gse}$ & $\mathrm{ng}^{-1}$ & & - \\
\hline Experiment & 1 & 0.4948 & 0.0897 & 0.0280 & 0.0095 & 0.8704 & 0.0981 \\
\hline Replicate (Experiment) & 10 & 0.2085 & 0.0142 & 0.0907 & 0.0059 & 0.0463 & 0.0017 \\
\hline Year & 1 & 0.0610 & 0.0035 & 0.0461 & 0.0012 & 0.0437 & 0.0016 \\
\hline Experiment $\times$ year & 1 & 0.0090 & 0.0012 & 0.0553 & 0.0019 & 0.0591 & 0.0032 \\
\hline Error a & 10 & 0.0183 & 0.0020 & 0.0377 & 0.0025 & 0.0502 & 0.0037 \\
\hline Cycle & 3 & 0.0446 & 0.0017 & 0.1423 ** & $0.0120^{*}$ & $0.0920^{\star \star \star}$ & $0.0064^{\star \star}$ \\
\hline Cycle linear & 1 & 0.0972 * & 0.0028 & 0.4106 ** & $0.0342^{* \star}$ & $0.2518^{* \star \star}$ & 0.0186 *** \\
\hline Cycle quadratic & 1 & 0.0000 & 0.0001 & 0.0005 & 0.0005 & 0.0233 * & 0.0003 \\
\hline Deviation from quadratic & 1 & 0.0367 & 0.0022 & 0.0157 & 0.0011 & 0.0011 & 0.0002 \\
\hline Experiment $\times$ cycle & 3 & 0.0086 & 0.0003 & 0.0154 & 0.0024 & 0.0037 & 0.0010 \\
\hline Year $\times$ cycle & 3 & 0.0187 & 0.0009 & 0.0036 & 0.0006 & 0.0032 & 0.0004 \\
\hline Experiment $\times$ year $\times$ cycle & 3 & 0.0154 & 0.0004 & 0.0004 & 0.0003 & 0.0028 & 0.0003 \\
\hline Error b & 60 & 0.0193 & 0.0017 & 0.0110 & 0.0012 & 0.0125 & 0.0012 \\
\hline
\end{tabular}

${ }^{*},{ }^{* *},{ }^{* \star *}$ indicate significance at the $0.1,0.05$, and 0.01 levels of probability, respectively. Dry matter concentration was not significant for all sources of variation for each grass.

Table 3. Mean seedling weights for switchgrass, indiangrass, and big bluestem populations produced by three cycles of stratified mass selection averaged over $2 \mathrm{yr}$ of seed production and two greenhouse evaluation experiments and the associated regression analyses of breeding cycle seedling weight means on breeding cycle.

\begin{tabular}{|c|c|c|c|c|c|c|}
\hline \multirow{2}{*}{$\begin{array}{l}\text { Cycle of } \\
\text { Selection }\end{array}$} & \multicolumn{2}{|c|}{ Switchgrass } & \multicolumn{2}{|c|}{ Indiangrass } & \multicolumn{2}{|c|}{ Big bluestem } \\
\hline & Fresh weight & Dry weight & Fresh weight & Dry weight & Fresh weight & Dry weight \\
\hline & & & gs & -1 & & - \\
\hline Cycle 0 & 0.610 & 0.156 & 0.536 & 0.137 & 0.598 & 0.147 \\
\hline Cycle 1 & 0.673 & 0.167 & 0.576 & 0.153 & 0.618 & 0.153 \\
\hline Cycle 2 & 0.649 & 0.159 & 0.669 & 0.179 & 0.655 & 0.170 \\
\hline Cycle 3 & 0.713 & 0.174 & 0.700 & 0.185 & 0.738 & 0.183 \\
\hline CV \% & 21 & 25 & 17 & 21 & 17 & 21 \\
\hline \multirow[t]{2}{*}{ LSD 0.05} & 0.139 & NS & 0.105 & 0.034 & 0.112 & 0.034 \\
\hline & \multicolumn{6}{|c|}{ Response to selection regression analyses } \\
\hline Regression $r^{2}$ & $0.73(P \leq 0.20)$ & 0.53 & $0.96^{\star \star}$ & $0.93^{\star \star}$ & $0.99^{\star \star}$ & $0.99^{\star \star}$ \\
\hline$b$ linear & 0.029 & 0.005 & 0.059 & 0.016 & -0.0016 & 0.007 \\
\hline b quadratic & & & & & 0.016 & 0.002 \\
\hline
\end{tabular}

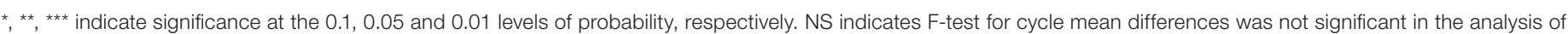
variance (Table 2$) ; b$ values are the regression coefficients for the change in seedling weight ( $g_{\text {seedling }}^{-1}$ ) per breeding cycle; CV, coefficient of variation.

production interaction effects were not significant for all three species, indicating the results were consistent over years of seed production (Table 2). It should be noted, however, that the mean square for year of seed production (year) was greater in magnitude than the mean square for cycles of switchgrass, indicating the effect that year of seed production can have on seedling growth and development of switchgrass seedlings. In the greenhouse trials, each of the breeding cycles for the three grasses produced seedlings with a mean seedling wet and dry weight greater than the previous generation except for switchgrass C2 (Table 3). The increases in seedling weight were significant for big bluestem and indiangrass for each breeding cycle (Table 2 and 3) but not for switchgrass. However, the breeding cycle linear effect was significant for switchgrass for fresh seedling weight with $P \leq 0.10$ (Table 2), indicating that over the three cycles, some breeding progress had been made.
The cycle linear effect was also significant for big bluestem and indiangrass with $P \leq 0.01$ (Table 2), indicating that the response to selection for seedling shoot weight had been positive. There were no differences among breeding cycles for the three grasses for seedling dry matter concentration (data not shown), indicating that the increases in seedling weight were not due to an increase in succulence or tissue water concentration. For big bluestem, switchgrass, and indiangrass, the increase in seedling weight per cycle was $7.8,5.6$, and $10.2 \%$, respectively.

\section{Field Evaluation Trials}

The field trials used to evaluate seedling vigor as measured by seedling shoot weight were conducted during a drought period in eastern Nebraska (Fig. 1). Rainfall during the evaluation period was only about $20 \%$ of normal. These drought conditions occur periodically in 


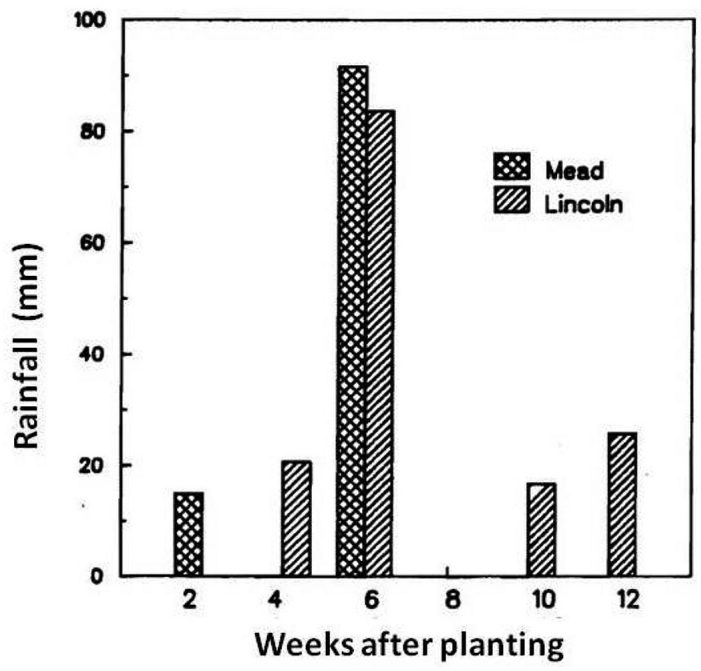

Figure 1. Rainfall at Lincoln and Mead, NE for the duration of the field experiments.

the Great Plains and are representative of adverse conditions under which improved seedling vigor would have the most value. The error variances for the Mead and Lincoln trials were not homogenous so the two trials were analyzed separately by grass species. In the field trials for all three grasses, years of seed production and breeding cycles $x$ years of seed production effects were again not significant nor were there any differences among the breeding cycle populations within a species for dry matter concentration (data and analysis not shown). In both the Lincoln and Mead field trials, there was a significant linear increase $(P \leq 0.05)$ in seedling weight for the breeding generations of the switchgrass populations (Table 4). In the big bluestem field trials, the differences among the breeding cycle means was not significant $(P \leq 0.05)$ but the linear response effect due to the three generations of recurrent breeding was significant at $P \leq 0.10$, indicating that over generations, the response to selection for seedling shoot weight had been positive. In the Lincoln field trial, there were significant differences among the indiangrass breeding cycle populations for both fresh and dry seedling weight, and the response to selection was significant and linear (Table 6). However, in the Mead indiangrass trials, there were no significant differences among breeding cycles for seedling shoot weight. For all three species, there were no significant differences among the strains for stand counts in either the Lincoln or Mead trials (Table $4,5,6)$. If the rows had been seeded in multirows spaced 18 to $30 \mathrm{~cm}$ apart, as is typical for pasture or rangeland plantings, all of the stands would have exceeded the fully adequate threshold of 20 plants $\mathrm{m}^{-2}$ (Launchbaugh and Owensby, 1970; Vogel and Masters 2001, Schmer et al., 2006). Seedling weight at $6 \mathrm{wk}$ after planting is a biological selection index that has several components including germination rate and post-germination seedling growth rate. The results of this study indicate that the breeding work for increasing seedling shoot weight significantly improved seedling shoot weight in the greenhouse selection environment and also improved seedling shoot weight in stressful field conditions, although the difference was not significant in one field environment for the indiangrass strains. The quantitative response to the breeding work indicates the effects of multiple genes, which would be expected because seedling weight at $6 \mathrm{wk}$ is a cumulative measure of several physiological processes in the development of seedlings. All of the seed lots used in the study were produced in well-managed nurseries and were planted within $2 \mathrm{yr}$ of seed harvest. All produced satisfactory stands in a year with limited precipitation during the establishment period, demonstrating the value of quality seed lots. In a previous study, Weiler (1984) evaluated the big bluestem, indiangrass, and switchgrass experimental strains used in this study for seedling weight in both the field and greenhouse using Syn 1 seed produced in different years from the original polycrosses. The results of Weiler's study were inconsistent and inconclusive. As indicated by the magnitude of the mean square for year of seed production (year) in Table 2 for switchgrass, the seed production environment can have a significant effect on seedling vigor as measured by seedling weight. The results of the greenhouse and field trials reported in this study indicate that seed lot effects were a likely source of the inconsistencies in the Weiler evaluation studies. The effect of the breeding work on improving seed size of the grasses could not be tested because the Syn 2 polycross nurseries were not replicated. The effect of the breeding work on seed size will have to be determined using replicated seed production plots but the seed from those plots will not be useful on determining the effect of the breeding work on seedling vigor because of the outcrossing between generations that would occur.

The switchgrass and big bluestem C3 populations developed in this breeding work were used by Smart et al. (2003a, 2003, 2004) to successfully conduct two generations of divergent breeding for either a single large tiller or multiple seedling tillers $(>3) 6 \mathrm{wk}$ after planting. The seedling tiller numbers were altered by the breeding work in both big bluestem and switchgrass, and tiller number differences were expressed in mature plants grown in noncompetitive spaced plant trials (Smart et al., 2004). In recent small plot sward trials co-conducted by coauthor Vogel, the big bluestem and switchgrass C3 seedling weight strains and their derived single and multitiller C2 switchgrass and big bluestem strains (Smart et al., 2003a,2003), all produced adequate stands (R.B. Mitchell and K.P. Vogel, personal communication, 2013). Boe and Ross (1998) have demonstrated that it is possible to breed for improved seed size in switchgrass. However, Smart and Moser (1999) stratified switchgrass seed lots into heavy and light classes and reported that, although seedlings grown from the heavy seed class had earlier shoot 
Table 4. Mean seedling weights and stand counts for switchgrass populations produced by three cycles of selection for seedling weight in field experiments at Lincoln and Mead, NE, associated $F$ tests, and the associated regression analyses of breeding cycle seedling weight means on breeding cycle.

\begin{tabular}{|c|c|c|c|c|c|c|}
\hline \multirow[b]{2}{*}{ Cycle of selection } & \multicolumn{3}{|c|}{ Lincoln } & \multicolumn{3}{|c|}{ Mead } \\
\hline & Fresh weight & Dry weight & Stand count & Fresh weight & Dry weight & Stand count \\
\hline & \multicolumn{2}{|c|}{ g seedling $^{-1}$} & seedling/2m & \multicolumn{2}{|c|}{ g seedling $^{-1}$} & seedling/2m \\
\hline Cycle 0 & 1.46 & 0.40 & 48.2 & 1.21 & 0.32 & 70 \\
\hline Cycle 1 & 1.71 & 0.48 & 48.3 & 1.31 & 0.33 & 76 \\
\hline Cycle 2 & 1.85 & 0.51 & 46.3 & 1.33 & 0.33 & 67 \\
\hline Cycle 3 & 2.33 & 0.67 & 59.1 & 1.62 & 0.39 & 66 \\
\hline \multicolumn{7}{|l|}{$F$-tests } \\
\hline Cycles & $* * \star$ & ** & & $\star * \star$ & ** & \\
\hline Cycles linear & $* \star \star$ & 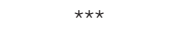 & & 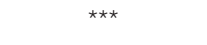 & $* * *$ & \\
\hline Cycles quadratic & & & & ** & ** & \\
\hline LSD 0.05 & 1.21 & 0.35 & NS & 0.18 & 0.13 & NS \\
\hline \multirow[t]{2}{*}{ CV \% } & 65 & 68 & 33 & 43 & 38 & 30 \\
\hline & \multicolumn{6}{|c|}{ Response to selection regression analyses } \\
\hline Regression $r^{2}$ & $0.97^{\star}$ & $0.97^{\star}$ & NS & $0.93^{*}$ & $0.92^{*}$ & NS \\
\hline$b$ linear & 0.103 & -0.039 & & -0.018 & -0.165 & \\
\hline$b$ quadratic & 0.058 & 0.035 & & 0.048 & 0.0125 & \\
\hline
\end{tabular}

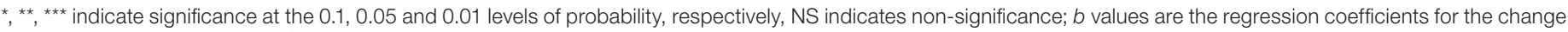
in seedling weight $\left(g\right.$ seedling $\left.{ }^{-1}\right)$ per breeding cycle.

Table 5. Mean seedling weights and stand counts for big bluestem populations produced by three cycles of selection for seedling weight in field experiments at Lincoln and Mead, NE, associated $F$-tests, and the associated regression analyses of breeding cycle seedling weight means on breeding cycle.

\begin{tabular}{|c|c|c|c|c|c|c|}
\hline \multirow{2}{*}{$\begin{array}{l}\text { Cycle of } \\
\text { selection }\end{array}$} & \multicolumn{3}{|c|}{ Lincoln } & \multicolumn{3}{|c|}{ Mead } \\
\hline & Fresh weight & Dry weight & Stand count & Fresh weight & Dry weight & Stand count \\
\hline & \multicolumn{2}{|c|}{ g seedling $^{-1}$} & seedling/2m & \multicolumn{2}{|c|}{ g seedling $^{-1}$} & seedling/2m \\
\hline Cycle 0 & 2.84 & 0.83 & 44 & 0.63 & 0.15 & 48 \\
\hline Cycle 1 & 3.88 & 1.12 & 52 & 0.70 & 0.19 & 57 \\
\hline Cycle 2 & 3.41 & 0.98 & 57 & 0.96 & 0.24 & 40 \\
\hline Cycle 3 & 4.53 & 1.28 & 45 & 0.97 & 0.26 & 56 \\
\hline \multicolumn{7}{|l|}{$F$ tests } \\
\hline Cycles & NS & NS & NS & NS & NS & NS \\
\hline Cycles linear & * & * & & * & * & \\
\hline \multicolumn{7}{|l|}{ Cycles quadratic } \\
\hline CV\% & 62 & 63 & 34 & 67 & 76 & 42 \\
\hline \multirow[t]{2}{*}{ LSD 0.05} & NS & NS & NS & NS & NS & NS \\
\hline & \multicolumn{6}{|c|}{ Response to selection regression analyses } \\
\hline $\begin{array}{l}\text { Regression } r^{2} \\
b \text { linear } \\
b \text { quadratic } \\
\end{array}$ & NS & NS & NS & NS & NS & NS \\
\hline
\end{tabular}

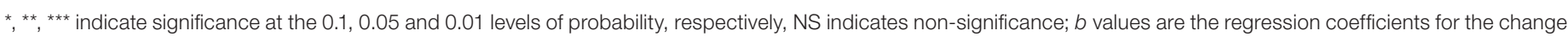
in seedling weight $\left(g^{\text {seedling }}{ }^{-1}\right.$ ) per breeding cycle.

growth and adventitious root growth than those grown from the light seed, seedlings from both classes were similar in development after 8 to $10 \mathrm{wk}$ after emergence, which indicates the importance of seed quality.

\section{CONCLUSIONS}

The results of this study and the subsequent research on breeding to change tiller morphology in big bluestem and switchgrass (Smart et al. 2003a, 2003b, 2004) clearly demonstrate that it is possible to breed for increased seedling weight and seedling tiller number in these grasses. However, the subsequent field evaluation work on establishment indicates that when high quality seed is used to establish these grasses, the genetic changes in seedling weight or tiller number that have been achieved to date, did not result in significant improvements in establishment of these grasses in well-managed trials. Trials have not been conducted to determine if they improve establishment under poor management conditions. In comparison to cultivated crops, the establishment of these grasses needs improvement. It is suggested that additional research is needed on improving seed quality of these grasses via improved seed production practices including irrigation, timely applications of herbicides and pesticides, seed harvest methods, and improved seed processing and testing technologies in addition to continued breeding work on improving seedling vigor. In addition, improvements in establishment practices are still needed. 
Table 6. Mean seedling weights and stand counts for indiangrass populations produced by three cycles of selection for seedling weight in field experiments at Lincoln and Mead, NE, associated $F$ tests, and the associated regression analyses of breeding cycle seedling weight means on breeding cycle.

\begin{tabular}{|c|c|c|c|c|c|c|}
\hline \multirow{2}{*}{$\begin{array}{l}\text { Cycle of } \\
\text { selection }\end{array}$} & \multicolumn{3}{|c|}{ Lincoln } & \multicolumn{3}{|c|}{ Mead } \\
\hline & Fresh weight & Dry weight & Stand count & Fresh weight & Dry weight & Stand count \\
\hline & \multicolumn{2}{|c|}{ g seedling $^{-1} \longrightarrow$} & seedling/2m & \multicolumn{2}{|c|}{$\longrightarrow$ g seedling $^{-1}$} & seedling/2m \\
\hline Cycle 0 & 2.20 & 0.65 & 102 & 0.88 & 0.24 & 68 \\
\hline Cycle 1 & 2.30 & 0.67 & 81 & 0.91 & 0.23 & 55 \\
\hline Cycle 2 & 3.44 & 0.99 & 95 & 1.04 & 0.29 & 69 \\
\hline Cycle 3 & 4.11 & 1.14 & 115 & 1.15 & 0.31 & 65 \\
\hline \multicolumn{7}{|l|}{$F$ tests } \\
\hline Cycles & $\star \star$ & ** & & NS & NS & NS \\
\hline Cycles linear & *** & *** & & $P<0.20$ & $P<0.20$ & NS \\
\hline \multicolumn{7}{|l|}{ Cycles quadratic } \\
\hline CV\% & 37 & 35 & 19 & 50 & 48 & 31 \\
\hline \multirow[t]{2}{*}{ LSD 0.05} & 1.13 & 0.31 & NS & 0.51 & 0.13 & NS \\
\hline & \multicolumn{6}{|c|}{ Response to selection regression analyses } \\
\hline Regression $r^{2}$ & $0.92^{*}$ & $0.91^{*}$ & & $0.95^{*}$ & $0.81^{*}$ & NS \\
\hline $\begin{array}{l}b \text { linear } \\
b \text { quadratic }\end{array}$ & 0.687 & 0.179 & & 0.094 & 0.027 & \\
\hline
\end{tabular}

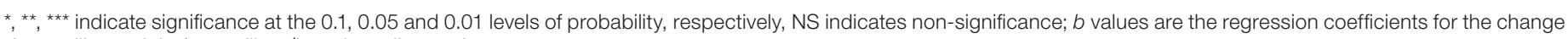
in seedling weight $\left(\mathrm{g}^{\text {seedling }}{ }^{-1}\right.$ ) per breeding cycle.

\section{Acknowledgments}

The evaluation phase of this research was completed in partial fulfillment of requirements for the Master of Science Degree by B. Sebolai at the University of Nebraska-Lincoln. Mention of trade names or commercial products in this publication is solely to provide specific information and does not imply recommendations or endorsement by the U.S. Department of Agriculture. USDA is an equal opportunity employer.

\section{References}

Boe, A., and J.G. Ross. 1998. Registration of 'Sunburst' switchgrass. Crop Sci. 38:540-540. doi:10.2135/cropsci1998.0011183X003800 $020058 \mathrm{x}$

Falconer, D.S. 1981. Introduction to quantitative genetics. 2nd ed. Longman, New York.

Glewen, K.L., and K.P. Vogel. 1984. Partitioning the genetic variability for seedling growth in sand bluestem into its seed sized and seedling vigor components. Crop Sci. 24:137-141. doi:10.2135/cropsci1984.0 011183X002400010032x

Kneebone, W.R. 1972. Breeding for seedling vigor. In: V.B. Younger and C.M. McKell, editors, The biology and utilization of grasses. Academic Press, New York. p. 90-100.

Launchbaugh, J.L., and C.E. Owensby. 1970. Seeding rate and first years stand relationships for six native grasses. J. Range Manage. 23:414-417. doi:10.2307/3896311

Masters, R.A. 1995. Establishment of big bluestem and sand bluestem cultivars with metolachlor and atrazine. Agron. J. 87:592-596. doi:10.2134/agronj1995.00021962008700030033x

Masters, R.A., S.J. Nissen, R.E. Gaussoin, D.D. Beran, and R.N. Stougaard. 1996. Imidazolinone herbicides improve restoration of Great Plains grasslands. Weed Technol. 10:392-403.

McKell, C.M. 1972. Seedling vigor and seedling establishment. In: V.B. Younger and C.M. McKell, editors, The biology and utilization of grasses. Academic Press, New York. p. 74-89.

Mitchell, R.B., K.P. Vogel, J. Berdahl, and R.A. Masters. 2010. Herbicides for establishing switchgrass in the Central and Northern Great Plains. BioEnergy Research 3:321-327. doi:10.1007/s12155-010-9084-4

Mitchell, R., K.P. Vogel, and D.R. Uden. 2012. The feasibility of switchgrass for biofuel production. Biofuels 3:47-59. doi:10.4155/ bfs.11.153
Perrin, R.K., K.P. Vogel, M.R. Schmer, and R.B. Mitchell. 2008. Farm-scale production cost of switchgrass for biomass. Bioenergy Research 1:91-97.

SAS Institute. 1989. SAS version 6. SAS Institute Inc., Cary, NC.

Schmer, M.R., K.P. Vogel, R.B. Mitchell, L.E. Moser, K.M. Eskridge, and R.K. Perrin. 2006. Establishment stand thresholds for switchgrass grown as a bioenergy crop. Crop Sci. 46:157-161. doi:10.2135/ cropsci2005.0264

Schmer, M.R., K.P. Vogel, R.B. Mitchell, and R.K. Perrin. 2008. Net energy of cellulosic ethanol from switchgrass. Proc. Natl. Acad. Sci. U. S. A. 105:464-469. doi:10.1073/pnas.0704767105

Smart, A.J., and L.E. Moser. 1999. Switchgrass seedling development as affected by seed size. Agron. J. 91:335-338.

Smart, A.J., L.E. Moser, and K.P. Vogel. 2003a. Establishment and seedling growth of big bluestem and switchgrass populations divergently selected for seedling tiller number. Crop Sci. 43:1434-1440. doi:10.2135/cropsci2003.1434

Smart, A.J., L.E. Moser, and K.P. Vogel. 2004. Morphological characteristics of big bluestem and switchgrass plants divergently selected for seedling tiller number. Crop Sci. 44:607-613.

Smart, A.J., K.P. Vogel, L.E. Moser, and W.W. Stroup. 2003b. Divergent selection for seedling tiller number in big bluestem and switchgrass. Crop Sci. 43:1427-1433. doi:10.2135/cropsci2003.1427

Vogel, K.P., and R.A. Masters. 2001. Frequency grid-A simple tool for measuring grassland establishment. J. Range Manage. 54:653-655. doi:10.2307/4003666

Voigt, P.W., and H.W. Brown. 1969. Phenotypic recurrent selection for seedling vigor in side-oats grama, Bouteloua curtipendula (Michx.) Torr. Crop Sci. 9:664-666. doi:10.2135/cropsci1969.0011183X000 $900050048 \mathrm{x}$

Washburn, B.E., and T.G. Barnes. 2000. Native warm-season grass and forb establishment using imazapic and 2, 4-D. Native Plants J. 1:61-69.

Weiler, R.B. 1984. Evaluation of seedling vigor in three warm-season grasses selected for high seedling shoot weight. M.S. thesis, Univ. of Nebraska-Lincoln, Lincoln.

Wright, N. 1977. Germination rate and growth responses of seed weight genotypes of Panicum antidotale Retz. Crop Sci. 17:176-178. doi:10.2135/cropsci1977.0011183X001700010046x

Wright, N. 1978. Recurrent selection for changing gene frequency of germination rate in blue panicgrass. Crop Sci. 18:789-791. doi:10.2135/cropsci1978.0011183X001800050025x

Wright, N. 1980. Germination rate and growth characteristics of blue panicgrass. Crop Sci. 20:42-44. doi:10.2135/cropsci1980.0011183X 002000010010x 